\title{
Changes in carabid beetle assemblages as Norway spruce plantations age
}

\author{
T. Magura ${ }^{1}$, B. Tóthmérész ${ }^{2}$ and Z. Elek ${ }^{3}$
}

1 Hortobágy National Park Directorate, Debrecen, POB. 216., H-4002 Hungary. Fax: +36

52 529-940. Corresponding author, e-mail: magura@www.hnp.hu

2 Ecological Institute, Debrecen University, Debrecen, POB. 71, H-4010 Hungary

3 Department of Ecology, Szent István University, Faculty of Veterinary Sciences, Budapest, POB 2, H-1400 Hungary

Keywords: Beech forest, Forest affinity indices, Forest carabid species, Generalist species, Open-habitat carabid species.

\begin{abstract}
Several managed native forest stands have been reforested with conifer trees in Europe during recent centuries. These habitat alterations have influenced ground-dwelling invertebrates. We studied carabid beetle assemblages from a native beech forest (70-y-old), and a recently established (5-y-old), a young (15-y-old), a middle-aged (30-y-old) and a mature (50-y-old) Norway spruce plantation by pitfall trapping to explore the effect of reforestation on carabid beetles. The total number of carabid species, and the forest species were highest in the beech forest. The number of open-habitat species was highest in the youngest, relatively open monoculture. Ordination also confirmed changes in carabid composition with change in the studied habitats. Newly proposed forest affinity indices, based on species specificity, fidelity, and on a combination of specificity and fidelity were significantly higher in beech forest than in spruce plantations. We found these affinity indices especially useful in revealing the ecological character of the studied carabid assemblages. Regression analyses showed that leaf litter cover, herbs, shrubs, canopy closure and prey abundance were related to the structure of carabid-beetle assemblages.
\end{abstract}

Abbreviations: FAI - Forest Affinity Index, FSI - Forest affinity Index based on Specificity, FFI - Forest affinity Index based on Fidelity, FSFI - Forest affinity Index based on both Specificity and Fidelity, ANOVA - ANAlysis of VAriance, NMDS - Nonmetric Multidimensional scaling. 
Magura et al., 2

Nomenclature for carabids follows: Hurka (1996) 


\section{Introduction}

In Europe, forest practices have caused drastic changes in the proportion of native and non-native forest stands. In Hungary, where $19.2 \%$ of the land surface is forested, nearly half $(43 \%)$ of that area consists of non-native trees (Norway spruce, scotch pine, black pine, black locust, poplar etc.). After clear-cutting of the native forests, which is the most widespread forestry practice in Hungary, $40 \%$ of the total clear felled areas are treated for the seedlings by mechanical soil preparation (deep loosening). Non-native Norway spruce (Picea abies) has been preferred for reforestation because of its quick growth and high economic value (Mátyás 1996). Clear-cutting, mechanical soil preparation and creation of even-aged conifer plantations have drastically altered the abiotic and biotic conditions and led to spatial homogenisation of the reforested habitats (Mátyás 1996). However, small-scale heterogeneity within forest stands considerably enhances local species richness and supports the existence of specialised species (Niemelä 1997).

Ground-dwelling carabid beetles (Coleoptera: Carabidae) are appropriate organisms to study the impacts of habitat alteration, because they are sufficiently diverse both taxonomically and ecologically. Moreover, they are abundant and their ecology and systematics are relatively well known (Lövei and Sunderland 1996). Previous studies have demonstrated that carabids are especially sensitive to soil disturbance and to other changes in environmental conditions (Niemelä et al. 1993, Niemelä 1999, Desender et al. 1999, Magura et al. 2001a, 2003, Koivula, 2002).

There have been several studies concerning the effects of clear-cutting of native conifer forests, and succession following it, on carabid assemblages in North America (Niemelä et al. 1993); Finland (Niemelä et al. 1996, Koivula et al. 2002), United Kingdom (Butterfield et al. 1995, Butterfield 1997, Humphrey et al. 1999, Ings and Hartley 1999, Jukes et al. 2001) and Ireland (Fahy and Gormally 1998). Data on the impacts of non-native conifer trees on carabids have also been published (Šustek 1981, Szyszko 1987, Baguette and Gérard 1993, Magura et al. 1997, 2002, Bonham et al. 2002).

We compared the differences in carabid assemblages between a native beech forest and Norway spruce plantations of various age; in the case of each plantation the native beech forest was clear-felled and after mechanical soil preparation the area was reforested with Norway 
spruce. Our aims were: (1) to study alterations in species composition of carabid assemblages after reforestation, (2) to examine changes in the forest affinity index (Allegro and Sciaky 2002) of carabids for stages of the plantation, (3) to develop improved forest affinity indices which use species specificity, fidelity, and their combination and are therefore not sensitive to high frequencies of some species, (4) to evaluate differences in the abundance of carabids with different habitat preferences in the native beech forest and in Norway spruce plantations of various age. These habitat affinity indices are good complements of the generally used diversity indices (Bauer et al. 2004, Izsák 2005, Lövei 2005, Ohlenmüller et al. 2004, Ricotta 2005a, 2005b).

\section{Materials and methods}

\section{Study area and sampling design}

The study was carried out in the North Hungarian Mountain Range, in the Bükk National Park $\left(48^{\circ} 05^{\prime} \mathrm{N}, 20^{\circ} 37^{\prime} \mathrm{E}\right)$. Within a circle of $4 \mathrm{~km}$ radius, we selected a beech forest stand and four stands representing different stages of Norway spruce plantations: (1) Beech forest with a sparse shrub layer and moderate herb layer. The average canopy cover is $90 \%$. Beech (Fagus sylvatica) is the dominant tree species, however hornbeam (Carpinus betulus), maple (Acer campestris, Acer pseudoplatanus) and ash (Fraxinus excelsior) are also present as an admixture. This forest type is the most widespread, typical forest in the region. (2) 5 -y-old non-native Norway spruce plantation with open canopy (average cover $20 \%$ ). Weeds, grasses and other plants typical of open habitats are dominant in the dense herb layer. The shrub layer is moderate. (3) 15-y-old Norway spruce plantation with sparse herb and shrub layer. The canopy layer has already closed (average canopy cover $80 \%$ ). (4) 30-y-old Norway spruce plantation almost entirely without understorey. The average cover of the canopy is $80 \%$. (5) 50 -y-old Norway spruce plantation. The canopy closure is smaller (average value $75 \%$ ), because of the loss of trees caused by windstorm. Decrease of the canopy closure results in a moderate herb layer. Each plantation was established after clear-cutting of beech forest, following mechanical soil preparation. All studied stands were on a NW-slope on limestone base rock; the distance between them was more than $1 \mathrm{~km}$. The size of the stands varied from 5 to 20 ha, large enough to have stand-age specific carabid species and not only immigrants from surrounding 
habitats (Mader 1984).

Carabid beetles were collected with unbaited pitfall traps consisting of plastic cups (diameter $100 \mathrm{~mm}, 500 \mathrm{ml}$ ), half-filled with $75 \%$ ethylene-glycol and detergent. The traps were covered with bark pieces to protect them from litter and rain input (Spence and Niemelä 1994). Traps were operated continuously from the beginning of March to the end of November in both 1998 and 1999, and were emptied monthly. For numerical analyses we pooled samples from the different months in each year. In each stand, 16 pitfall traps were placed randomly. The distance between traps was always larger than $5 \mathrm{~m}$. In each stand, traps were at least $40 \mathrm{~m}$ apart from the nearest forest edge in order to avoid edge effects (Kotze and Samways 1999, Magura et al. 2000b, 2001b, Magura 2002, Molnár et al. 2001). Digweed et al. (1995) suggest that traps 10 metres apart or closer are not statistically independent. To test for spatial independence in the trapping arrangement, Elek et al. (2005) examined the similarities between traps in the function of their spatial distance. Traps can be regarded as independent when the average similarity shows no trend with increasing distance. We tested our catches using this method and we did not find such kind of trend in the similarities. This means that there was no spatial autocorrelation and the traps can be regarded independent observations.

In order to study the relationship between species richness of carabids and environmental variables, eleven environmental factors that may be relevant to the distribution of carabids were measured or estimated (Thiele 1977, Lövei and Sunderland 1996). Ground temperature at 2 cm depth in the soil, air temperature on the soil surface, relative humidity on the soil surface, soil $\mathrm{pH}$ and compactness and organic matter content of the soil were measured adjacent to each trap. We also estimated the cover of leaf litter, herbs, shrubs and canopy around the traps within a circle of 2 m diameter. Other estimation methods may also relevant (Moffatt et al. 2005). We also studied the food source of carabids, by counting the number of individuals of other invertebrates (other Coleoptera, Chilopoda, Collembola, Diplopoda, Gastropoda, and Isopoda) in the traps (Sergeeva 1994).

\section{Data analyses}

We studied whether carabid-beetle assemblages changed during ageing of Norway spruce 
plantations. Since the species richness of an assemblage does not always correlate with the ecological stability or naturalness of the habitat, a new ecological index, the forest affinity index ( FAI ), which is able to assess the relative quality of a habitat compared to another habitat, was proposed by Allegro and Sciaky (2002). The value of the forest affinity indices is higher when more forest species are present in the habitat. The forest affinity index $(F A I)$ is calculated as follows:

$$
F A I=\sum_{i=1}^{S} p_{i} F_{i}
$$

where $p_{i}$ is the relative frequency of species $i$, and $F_{i}$ is the value of the forest specialisation of species $i ; S$ is the total number of species. $F_{i}$ values have five levels: +1 : obligate forest species, +0.5 : partial forest species, 0 : species indifferent to forest coverage (habitat generalists), -0.5 : partial open-habitat species, and -1 : obligate open-habitat species. The FAI value varies between +1 and -1 . Higher $F A I$ values indicate that there are more forest species in the habitat (Allegro and Sciaky 2002). The $F_{i}$ coefficients of the species were determined according to literature (Hurka 1996); results of earlier widespread researches in the study region were also used as additional information (Magura et al. 2002, 2003). Therefore, it is based on a wide range of knowledge and research experience regarding the ecological character of these species.

The abundance and consequently the relative frequency of a species may differ with habitat types because each species has characteristic catch properties, such as activity pattern and life history traits (Luff 1975). For this reason, an index that removes the effect of abundance differences among compared habitats and simultaneously takes into account the specificity of species is needed. The consistency of the occurrence of a species in a habitat type is also very important in the calculation of an affinity index, namely at how many sites a species is present within a habitat type (fidelity). As a consequence of these arguments, we propose three new forest affinity indices which include the components of specificity, fidelity, and both of them in the calculation process. Calculating specificity is based on the method proposed by Dufrêne and Legendre (1997).

The forest affinity index based on specificity ( FSI ) is calculated as follows:

$$
F S I=\sum_{i=1}^{S} \frac{\bar{x}_{i j}}{\bar{x}_{i .}} F_{i}
$$


where $\bar{x}_{i j}$ is the mean number of individuals of species $i$ across traps of habitat $j, \bar{x}_{i \text {. }}$ is the sum of the mean numbers of individuals of species $i$ over all habitats.

The forest affinity index based on fidelity $(F F I)$ is calculated as follows:

$$
F F I=\sum_{i=1}^{S} \frac{n_{i j}}{n_{i .}} F_{i},
$$

where $n_{i j}$ is the number of traps in habitat $j$ where species $i$ is present, $n_{i}$. is the total number of traps in habitat $j$.

The forest affinity index based on both specificity and fidelity ( FSFI ) is calculated as follows:

$$
F S F I=\sum_{i=1}^{S} \frac{\bar{x}_{i j}}{\bar{x}_{i .}} \frac{n_{i j}}{n_{i .}} F_{i},
$$

where the notations are the same as earlier.

The three new indices are not limited to -1 and +1 contrary to $F A I$. We calculated the affinity values at the trap level, while Allegro and Sciaky (2002) calculated the affinity values for the habitats.

Carabid species were divided into three ecological groups to study changes in species richness with ageing of Norway spruce plantation: forest species, open-habitat species, and habitat generalists. Moreover, forest species were further divided into partial and obligate forest species (Table 1; Thiele 1977, Hurka 1996).

The values of forest affinity indices, total number of species, and species richness of the ecological groups of carabids were examined by repeated measures analysis of variance (ANOVA) among stages of Norway spruce plantations at the trap level. If ANOVA indicated significant differences among stages, Tukey's multiple comparisons were used to detect which stages differed from others. The normal distribution of the data was achieved by $\log (x+1)$ transformation (Sokal and Rohlf 1981).

Changes in the number of carabid species (total, forest species, open-habitat species, generalist species, partial forest species, and obligate forest species) per trap during ageing of spruce plantations was investigated by linear regression analysis using data for the two years. We 
examined relationships between environmental measurements and carabid species richness by stepwise multiple linear regression for the data from the two years.

The Hellinger distance (also known as Bhattacharyya distance) was used to measure the similarity of traps (Basu et al. 1997), and non-metric multidimensional scaling (NMDS) was used as an ordination method to display the similarity between pitfall catches for the two years in the beech forest and in the plantations (Legendre and Legendre 1998).

\section{Results}

\section{Assemblage Structure}

The carabid catches consisted of 40 species and 4622 individuals (Table 1). The most abundant species was Abax parallelepipedus, with 1521 individuals (32.9\% of the total carabid catch). The captured species consisted of 18 forest species, 11 open-habitat species and 11 generalist species (Table 1).

The total species richness and the number of forest species were significantly higher in the beech forest than in the Norway spruce plantations. Moreover, the number of generalist species in the beech forest and the 5 -y-old plantation were significantly higher than those in the older plantations. The number of open-habitat species was the highest in the youngest monoculture (Fig. 1 and Table 2).

\section{Forest Affinity Indices and Forest Species}

The value of the forest affinity index based on species frequencies was significantly higher in the beech forest, the 30-y-old and the 50-y-old plantations than in the 5-y-old and 15-y-old plantations. The values of the three newly proposed forest affinity indices based on specificity, on fidelity, and on both specificity and fidelity, were significantly higher in the beech forest than in all Norway spruce plantations (Fig. 2 and Table 3).

Both the number of partial forest species and obligate forest species, as well as the ratio of individuals of obligate forest species to the total number of individuals were higher in the beech 
forest compared to the plantations (Table 4). The ratio of individuals of partial forest species to total carabid beetles was significantly higher in the two oldest spruce plantations than in other habitats (Table 4).

\section{Changes in assemblages during ageing of spruce plantations}

Ordination results suggest that pronounced changes in carabid species composition occur after reforestation and during ageing of plantations, as traps from the habitat with open canopy (5-y-old plantation) were separated from habitats with closed canopy (beech forest and the three oldest spruce plantations) along axis one, the 5-y-old and the 30-y-old plantations being most distant. Traps from the beech forest were separated from the 50-y-old plantation along axis two (Fig. 3).

Linear regression analysis showed that the total number of species decreased, the number of forest species increased, the number of open-habitat species decreased, the number of generalist species decreased, the number of partial forest species increased and the number of obligate forest species did not change as the non-native Norway spruce plantations aged (Table 5).

Results of stepwise linear regression showed that cover of leaf litter, herbs, shrubs, canopy closure and amount of prey items were the most important factors influencing the structure of carabid-beetle assemblages (Table 6).

\section{Discussion}

\section{Usefulness of forest affinity indices}

Results concerning the proportion of forest species in carabid assemblages differed depending on the forest affinity index used. The value of the forest affinity index based on frequencies was highest in the beech forest and in the two oldest plantations, while the value of the forest affinity index was higher in the beech forest than in all the plantations when we used specificity and/or fidelity. This contradiction is due to the bias in the forest affinity index using species frequencies to characterize the dominance structure of the assemblages. This index yields a high value if only some partial forest species are present with high frequencies in a habitat, 
while it gives a lower value for a species-rich assemblage with a uniform frequency distribution. In the studied situation, there were significantly fewer forest (both partial and obligate) species in the two oldest plantations compared to the beech forest. Moreover, most carabid individuals captured in the two oldest plantations also belonged to the partial forest species (Table 1). The number of forest species (both partial and obligate forest species) was significantly higher in the beech forest than in Norway spruce plantations, indicating that only the beech forest could maintain more specialised carabid species. This ecological value of the beech forest is expressed in the values of forest affinity indices using specificity and/or fidelity because these indices provided significantly higher values in the beech forest than in all plantations.

The forest affinity index using specificity can provide more adequate results than that based on frequency for two reasons. First, pitfall trapping for the same species can give different abundance and consequently relative frequencies between habitat types. Second, from an ecological point of view the species that occurs only in one habitat type can be regarded as an indicator species for this habitat. Even if this indicator species occurs in low numbers, it receives a higher value if we use the forest affinity index based on specificity.

Fidelity is also important in ecology, namely how many sampling sites a given species occupies within a habitat and how consistent the occurrence of this species is in a habitat type. Using the forest affinity index based on frequency, accidental immigrant species with high numbers of individuals but present only at some sampling sites within a habitat type receive a high value, while this artifact can be eliminated if we use the index based on fidelity. The forest affinity index based on both specificity and fidelity combines the two pieces of independent ecological information about species distribution, by expressing simultaneously how characteristic a species is for a given habitat and how consistent its occurrence is within a habitat.

\section{Changes of carabid assemblages in relation to ageing of spruce plantations}

Our results show that considerable changes occur in carabid species richness as Norway spruce plantations age. These changes also appear in the composition of the carabid assemblages because traps from the different habitats were separated from each other by ordination (Fig. 3).

The total number of carabid species decreased significantly after reforestation of the native beech forest with non-native Norway spruce and it did not recover during ageing of the 
plantation. Butterfield et al. (1995), who studied carabid assemblages in deciduous forests and in Sitka spruce (Picea sitchensis) plantations with closed canopy in northern England, also found that carabid species richness was lower in the plantations as compared to the deciduous forests. In Ireland Fahy and Gormally (1998), comparing carabid beetles in a semi-natural oak woodland with those of a nearby mature Sitka spruce plantation, concluded that carabid populations were significantly richer in species in the oak forest than in the conifer plantation.

The number of open-habitat species was higher in the youngest spruce plantation with open canopy. The recently created conifer plantation with open canopy is a new habitat for open-habitat species (e.g., Amara and Harpalus species) probably for microclimatic reasons. These species colonise the new habitat very quickly since they are macropterous. They usually disappear or their abundance decreases along with closure of the canopy. The change in the number of open-habitat species in the habitats studied is in agreement with results from previous studies (Baguette and Gérard 1993, Niemelä et al. 1993, Butterfield 1997, Werner and Raffa 2000, Jukes et al. 2001, Koivula et al. 2002) since they also showed that the number of open-habitat species was higher in young forests with open canopy than in aged ones with closed canopy. In our study, similarly to previous results (Niemelä et al. 1993), some open-habitat species were also captured in native forests with closed canopy. These individuals represent either populations of open-habitat species that remained after canopy closure, or vagrant beetles, since carabid species could disperse into forest habitats from the surrounding open habitats (Kotze and Samways 1999, Magura et al. 2000b, 2001b, Magura 2002, Molnár et al. 2001).

Our results indicated that the number of generalist species was higher in the beech forest and in the 5 -y-old spruce plantation compared to the three oldest spruce plantations. A previous study (Magura et al. 2003) conducted in the same region showed that in a native beech forest stand three times as many individuals could be trapped as in a spruce stand with trees of similar age with the same number of traps indicating that the carrying capacity of a beech stand is much higher. Clear-cutting and mechanical soil preparation could affect species adapted to the forest environment. Thus, the generalist species still present could colonise this habitat. Similarly to our results, Koivula (2002) and Koivula et al. (2002) also caught more generalist species in the early phase of the clear-cutting initiated succession of a boreal spruce forest. Koivula et al. (2002) showed that the majority of these generalist species were the most abundant in the youngest stand. 
Our results show that the number of forest carabid species was significantly higher in the native beech forest than in the non-native Norway spruce plantations. Species richness of the forest carabids slightly increased after canopy closure of plantations, although the species richness of forest carabids was much lower in the plantations than in the beech forest even 50 years after the establishment. The enhancement of the forest carabid species richness is due to an increase in the number of partial forest species as obligate forest species richness was small in plantations with both open and closed canopies suggesting that clear-cutting and creation of spatially homogenous plantations damage mainly populations of obligate forest species. Previous studies (Baguette and Gérard 1993, Niemelä et al. 1993, Werner and Raffa 2000, Jukes et al. 2001, Koivula et al. 2002) also reported that the number of forest species decreased after clear cutting and only slightly increased after closure of the canopy of conifer forests.

Our results showed that the species composition of carabid assemblages changed significantly by ageing of spruce plantations: (1) Clear-cutting the natural forest and creation of non-native spruce plantations resulted in a remarkable reduction in the number of forest carabid species (both partial and obligate forest species). (2) The number of partial forest species slightly increased during ageing of the plantation, although it did not reach the level of the native beech forest. (3) In the young plantation with open canopy layer open-habitat species were numerous. They either disappeared after canopy closure or their abundance decreased significantly. (4) Habitat generalist species are also influenced, as their species richness decreased during ageing of the plantations.

\section{Carabids and environmental factors}

Grüm (1971), analysing crop contents of carabids, showed that less than $15 \%$ of the individuals in a natural population were satiated and that proportion increased more than five-fold through food supplementation. Several studies (Baars and Van Dijk 1984, Brunsting and Heessen 1984) showed that the egg production and the number of eggs laid were largely dependent on the amount of food; the fecundity was the higher the more or the better food was provided. All these results indicate that food is generally limited for carabids in the field. Therefore, the amount of available prey can influence the spatial pattern of carabid beetles, and carabids can aggregate in a habitat with a higher amount of prey (Bryan and Wratten 1984). This can explain the positive relationship between the total number of carabid species and the amount of prey 
items.

The observed positive relationship between the cover of leaf litter and the number of forest carabid species can be attributed to abiotic factors. Leaf litter was shown to increase the number of carabid species through producing favourable microsites (Niemelä et al. 1992, Niemelä and Spence 1994). Leaf-litter can offer more stable temperature and humidity conditions which are important factors determining the spatial pattern of forest carabids (Thiele 1977). Leaf litter enabling vertical separation of competing species may decrease intra- and interspecific competition (Loreau 1988) and thereby contribute positively to the coexistence of several species in a habitat.

Significant correlations between the cover of leaf litter, herbs, shrubs, canopy and the number of open-habitat species are due to the habitat characteristics of the youngest plantation. In this habitat the cover of herbs and shrubs is high because of the more open tree canopy and because leaf litter does not accumulate on the ground surface. All these habitat characteristics provide abiotic environmental conditions (sunlight, higher surface temperature, drier soil conditions etc.) which are typical for an open habitat and therefore this 5-y-old plantation becomes attractive for open-habitat species.

Most open-habitat species captured in the youngest plantation feed on grass seeds and other plant materials. However, half of the individuals of open-habitat species belonged to Pseudoophonus rufipes which is omnivorous (Thiele 1977). Perhaps this is the reason why we could detect significant relationship between the amount of prey items and the number of open-habitat species.

The positive relationship between the number of generalist species and the cover of leaf litter is surprising, because Guillemain et al. (1997) showed that the number of habitat generalist carabid species could decrease by increasing the amount and thickness of leaf-litter. Perhaps the thick leaf litter may offer new niches, for example, by providing space for the vertical separation of the coexisting species. This could enable more generalist species to coexist in a given habitat (Magura et al. 2005). The negative correlation between the canopy cover and the number of generalist species could be explained either by the abolished competitive exclusion or by the habitat demand of these species. 
The number of partial forest species increased as the canopy cover increased. The number of these species increased as the plantation aged. There was a strong positive relationship between the number of obligate forest species and the cover of leaf litter. Leaf litter, through producing more stable temperature and humidity conditions, is a very important factor for obligate forest species which prefer cool and wet microsites (Thiele 1977, Niemelä et al. 1992).

\section{Implication for management}

Our results demonstrated that clear-cutting native beech forests for creating even-aged, homogeneous non-native Norway spruce plantations had a harmful effect on carabid beetle populations. In spite of the damaging influences of spruce plantations on carabids in this area, their destruction is almost impossible. The immediate exploitation of spruce plantations would cause financial loss to timber companies, and it has been shown that clear-cutting also has harmful effects on the environment and on the biota. Therefore, forestry practices should be used that are close to natural processes, as organisms can adapt to these kinds of processes (Niemelä 1999). To mimic natural windfall, openings or gaps must be logged in plantations (Koivula 2002), which deciduous herbs, shrubs and trees can colonise. Colonised deciduous plants enhance habitat heterogeneity, and provide refuges during logging of other gaps in the plantations. Magura et al. (2000a) also showed that creating gaps in Norway spruce plantations and facilitating the re-establishment of native herbs, shrubs and deciduous trees enhanced the regeneration of the native carabid assemblage. Forestry practices which preserve habitat heterogeneity should be introduced to maintain or even enhance biodiversity in managed forests. Since small-scale heterogeneity within forest stands considerably enhances local species richness and supports the existence of specialised species, spatial heterogeneity has recently been recognised as a key factor promoting the stability and diversity of ecological systems (Niemelä 1997). Koivula and Niemelä (2003) also regarded gap felling as a reasonable and environmentally friendly technique of forest harvesting.

\section{Acknowledgements}

We are especially grateful to Gábor Lövei for comments on the manuscript, and Viktor Ködöböcz for field and laboratory assistance. This research was supported by the grants of the Hungarian Scientific Research Fund (OTKA research grant no. F61651). 


\section{References}

Allegro, G. and R. Sciaky. 2002. Assessing the potential role of ground beetles (Coleoptera, Carabidae) as bioindicators in poplar stands, with a newly proposed ecological index (FAI). Forest Ecol. Manag. 175:275-284.

Basu, A., I. R. Harris, and S. Basu. 1997. Minimum distance estimation: The approach using density-based distances. In: G. S. Maddala and C. R. Rao, (eds), Handbook of Statistics, volume 15, pp. 21-48. North-Holland.

Baars, M.A. and Th.S. Van Dijk. 1984. Population dynamics of two carabid beetles at a Dutch heathland. II. Egg production and survival in relation to density. J. Anim. Ecol. 53:389-400.

Baguette, M. and S. Gérard. 1993. Effects of spruce plantations on carabid beetles in southern Belgium. Pedobiologia 37:129-140.

Bauer, N., Z. Kenyeres and T. Kisbenedek. 2004. A comparison of cluster analysis and diversity-ordering in community classification. Community Ecology 5:189

Bonham, K.J., R. Mesibov and R. Bashford. 2002. Diversity and abundance of some ground-dwelling invertebrates in plantation vs. native forests in Tasmania, Australia. Forest Ecol. Manag. 158:237-247.

Brunsting, M.H. and H.J.L. Heessen. 1984. Density regulation in the carabid beetle Pterostichus oblongopunctatus. J. Anim. Ecol. 53:751-760.

Bryan, K.M. and S.D. Wratten. 1984. The responses of polyphagous predators to spatial heterogeneity: aggregation by carabid and staphylinid beetles to their cereal aphid prey. Ecol. Entomol. 9:251-259.

Butterfield, J. 1997. Carabid community succession during forestry cycle in conifer plantations. Ecography 20:614-625.

Butterfield, J., M.L. Luff, M. Baines and M.D. Eyre. 1995. Carabid beetle communities as indicators of conservation potential in upland forests. Forest Ecol. Manag. 79:63-77.

Desender, K., A. Ervynck and G. Tack. 1999. Beetle diversity and historical ecology of woodlands in Flanders. Belg. J. Zool. 129:139-156.

Digweed, S.C., C.R. Currie, H.A. Cárcamo and J.R. Spence. 1995. Digging out the digging - in effect of pitfall traps: influences of depletion and disturbance on catches of ground beetles (Coleoptera: Carabidae). Pedobiologia 39, 561-576.

Dufrêne, M. and P. Legendre. 1997. Species assemblages and indicator species: the need for a 
flexible asymmetrical approach. Ecol. Monogr. 67:345-366.

Elek, Z., T. Magura and B. Tóthmérész. 2005. Effect of canopy closure of a young Norway spruce plantation on ground beetles. In: G.L. Lövei and S. Toft (eds), European Carabidology 2003. Proceedings of the 11th European Carabidologists' Meeting. DIAS Report, No. 114. Flakkebjerg, pp. 89-97.

Fahy, O. and M. Gormally. 1998. A comparison of plant and carabid beetle communities in an Irish oak woodland with a nearby conifer plantation and clearfelled site. Forest Ecol. Manag. 110:263-273.

Grüm, L. 1971. Spatial differentiation of the Carabus L. (Carabidae, Coleoptera) mobility. Ekologika Polska 19:1-34.

Guillemain, M., M. Loreau and T. Daufresne. 1997. Relationships between the regional distribution of carabid beetles (Coleoptera, Carabidae) and the abundance of their potential prey. Acta Oecol. 18:465-483.

Humphrey, J.W., C. Hawes, A.J. Peace, R. Ferris-Kaan and M.R. Jukes. 1999. Relationship between insect diversity and habitat characteristics in plantation forests. Forest Ecol. Manag. 113:11-21.

Hurka, K. 1996. Carabidae of the Czech and Slovak Republics. Kabourek, Zlin. Ings, T.C. and S.E. Hartley. 1999. The effect of habitat structure on carabid communities during the regeneration of a native Scottish forest. Forest Ecol. Manag. 119:123-136.

Izsák, J. 2005. Diversity and related statistics: a new version of the DIVERSI program. Community Ecology 6:249

Jukes, M.R., A.J. Peace and R. Ferris. 2001. Carabid beetle communities associated with coniferous plantations in Britain: the influence of site, ground vegetation and stand structure. Forest Ecol. Manag. 148:271-286.

Koivula, M. 2002. Boreal carabid-beetle (Coleoptera, Carabidae) assemblages in thinned uneven-aged and clear-cut spruce stands. Ann. Zool. Fenn. 39:131-149.

Koivula, M., J. Kukkonen and J. Niemelä. 2002. Boreal carabid-beetle (Coleoptera, Carabidae) assemblages along the clear-cut originated succession gradient. Biodivers. Conserv. 11:1269-1288.

Koivula, M. and J. Niemelä. 2003. Gap felling as a forest harvesting method in boreal forests: responses of carabid beetles (Coleoptera, Carabidae). Ecography 26:179-187.

Koivula, M., J. Kukkonen and J. Niemelä. 2002. Boreal carabid-beetle (Coleoptera, Carabidae) assemblages along the clear-cut originated succession gradient. Biodivers. Conserv. 11:1269-1288. 
Kotze, D. J. and M.J. Samways. 1999. Invertebrate conservation at the interface between the grassland matrix and natural Afromontane forest fragments. Biodivers. Conserv. 8:1339-1363. Legendre, P. and L. Legendre. 1998. Numerical Ecology. Elsevier, Amsterdam.

Loreau, M. 1988. Determinants of the seasonal pattern in the niche structure of a forest carabid community. Pedobiologia 31:75-87.

Lövei, G. L. 2005. Generalised entropy indices have a long history in ecology - a comment. Communty Ecology 6:245

Lövei, G. and K.D. Sunderland. 1996. Ecology and behavior of ground beetles (Coleoptera: Carabidae). Annu. Rev. Entomol. 41:231-256.

Luff, M.L. 1975. Some features influencing the efficiency of pitfall traps. Oecologia 19:345-357.

Mader, H.J. 1984. Animal habitat isolation by roads and agricultural fields. Biol. Conserv. 29:81-96.

Magura, T. 2002. Carabids and forest edge: spatial pattern and edge effect. Forest Ecol. Manag. 157:23-37.

Magura, T., V. Ködöböcz and Zs. Bokor. 2001a. Effects of forestry practices on carabids (Coleoptera: Carabidae) - Implication for nature management. Acta Phytopathol. Entomol. Hung. 36:179-188.

Magura, T., B. Tóthmérész and Zs. Bordán. 1997. Comparison of the carabid communities of a zonal oak-hornbeam forest and pine plantations. Acta Zool. Acad. Sci. Hung. 43:173-182.

Magura, T., B. Tóthmérész and Zs. Bordán. 2000a. Effects of nature management practice on carabid assemblages (Coleoptera: Carabidae) in a non-native plantation. Biol. Conserv. 93:95-102.

Magura, T., B. Tóthmérész and Z. Elek. 2002. Impacts of non-native spruce reforestation on ground beetles. Eur. J. Soil Biol. 38:291-295.

Magura, T., B. Tóthmérész and Z. Elek. 2003. Diversity and composition of carabids during a forestry cycle. Biodiv. Conserv. 12:73-85.

Magura, T., B. Tóthmérész and Z. Elek. 2005. Impacts of leaf-litter addition on carabids in a conifer plantation. Biodiv. Conserv. 14:475-491.

Magura, T., B. Tóthmérész and T. Molnár. 2000b. Spatial distribution of carabids along grass-forest transects. Acta Zool. Acad. Sci. Hung. 46:1-17.

Magura, T., B. Tóthmérész and T. Molnár. 2001b. Forest edge and diversity: carabids along forest-grassland transects. Biodiv. Conserv. 10:287-300.

Mátyás, Cs. 1996. Forestry Ecology. Mezőgazda Kiadó, Budapest. (in Hungarian) 
Moffatt, C., S. McNeill and A. J. Morton. 2005. The quantification of habitat architecture for explanations of arthropod assemblage patterns: a comparison of two methods. Community Ecology 5:83-92.

Molnár, T., T. Magura and B. Tóthmérész. 2001. Ground beetles (Carabidae) and edge effect in oak-hornbeam forest and grassland transects. Eur. J. Soil Biol. 37:297-300.

Niemelä, J. 1997. Invertebrates and boreal forest management. Conserv. Biol. 11:601-610.

Niemelä, J. 1999. Management in relation to disturbance in the boreal forest. Forest Ecol. Manag. 115:127-134.

Niemelä, J. and J.R. Spence. 1994. Distribution of forest dwelling carabids (Coleoptera): spatial scale and the concept of communities. Ecography 17:166-175.

Niemelä, J., Y. Haila, E. Halme, T. Pajunen and P. Punttila. 1992. Small-scale heterogeneity in the spatial distribution of carabid beetles in the southern Finnish taiga. J. Biogeogr. 19:173-181. Niemelä, J., D. Langor and J.R. Spence. 1993. Effects of clear-cut harvesting on boreal ground-beetle assemblages (Coleoptera: Carabidae) in western Canada. Conserv. Biol. 7:551-561.

Niemelä, J., Y. Haila and P. Punttila. 1996. The importance of small-scale heterogeneity in boreal forests: variation in diversity in forest-floor invertebrates across the succession gradient. Ecography 19:352-368.

Ohlemüller, R., P. Bannister, K. J. M. Dickinson, S. Walker, B. J. Anderson and J. B. Wilson 2004. Correlates of vascular plant species richness in fragmented indigenous forests: assessing the role of local and regional factors. Community Ecology 5:45

Ricotta, C. 2005a. An asymptotic fractal model for logistic species-area curves. Communty Ecology 6:109

Ricotta C. 2005b. On parametric diversity indices in ecology: A historical note. Communty Ecology 6:241

Sergeeva, T.K. 1994. Seasonal dynamics of interspecific trophic relations in a carabid beetle assemblage. In: K. Desender et al. (eds), Carabid beetles: ecology and evolution. Kluwer Academic Publishers, Dordrecht, pp. 367-370.

Sokal, R.R. and F.J. Rohlf. 1981. Biometry. W. H. Freeman, New York. Spence J.R. and J. Niemelä. 1994. Sampling carabid assemblages with pitfall traps: the madness and the method. Can. Entomol. 126:881-894.

Šustek, Z. 1981. Influence of clear cutting on ground beetles (Coleoptera, Carabidae) in a pine forest. Comm. Ins. Forestalis 12:243-254.

Szyszko, J. 1987. How can the fauna of Carabidae be protected in managed pine forest? Acta 
Phytopathol. Entomol. Hung. 22:293-303.

Thiele, H.U. 1977. Carabid Beetles in their Environments. Springer Verlag, Berlin.

Werner, S.M. and K.F. Raffa. 2000. Effects of forest management practices on the diversity of ground-occurring beetles in mixed northern hardwood forests of the Great Lakes Region. Forest Ecol. Manag. 139:135-155. 
Magura et al., 20

Table 1: The catches of carabid beetles in the stages of the studied forestry cycle and their forest specialisation value $\left(\mathrm{F}_{\mathrm{i}}\right)$, and their habitat preference in the studied region. Species represented by less than 10 individuals are listed in the footnote of Table 1. Notations: F - forest species, $\mathrm{O}$ open-habitat species, G - generalist species.

\begin{tabular}{|c|c|c|c|c|c|c|c|}
\hline \multirow[t]{2}{*}{ Species } & \multirow[t]{2}{*}{$\mathrm{F}_{\mathrm{i}}$} & \multirow{2}{*}{$\begin{array}{c}\text { Habitat } \\
\text { preference }\end{array}$} & \multirow[t]{2}{*}{ Beech } & $5 y$ & $15 \mathrm{y}$ & $30 \mathrm{y}$ & $50 \mathrm{y}$ \\
\hline & & & & \multicolumn{4}{|c|}{ plantation } \\
\hline Abax parallelepipedus (Pill. et Mitt.) & 0 & G & 538 & 60 & 477 & 321 & 125 \\
\hline Pterostichus melanarius Ill. & 0 & G & 215 & 28 & 117 & 137 & 0 \\
\hline Carabus violaceus L. & 0.5 & $\mathrm{~F}$ & 107 & 26 & 20 & 7 & 28 \\
\hline Abax parallelus (Dft.) & 0.5 & $\mathrm{~F}$ & 89 & 20 & 21 & 121 & 7 \\
\hline Molops piceus (Panz.) & 0 & $\mathrm{G}$ & 87 & 72 & 9 & 2 & 138 \\
\hline Carabus hortensis L. & 0.5 & $\mathrm{~F}$ & 73 & 7 & 189 & 165 & 41 \\
\hline Carabus nemoralis O. F. Müll. & 1 & $\mathrm{~F}$ & 73 & 3 & 10 & 8 & 5 \\
\hline Aptinus bombarda (Ill.) & 1 & $\mathrm{~F}$ & 51 & 14 & 2 & 1 & 9 \\
\hline Carabus convexus $\mathrm{F}$. & 0.5 & $\mathrm{~F}$ & 48 & 8 & 6 & 17 & 3 \\
\hline Pterostichus anthracinus (Ill.) & 0.5 & $\mathrm{~F}$ & 36 & 10 & 5 & 6 & 0 \\
\hline Cychrus caraboides (L.) & 0.5 & $\mathrm{~F}$ & 32 & 1 & 10 & 9 & 29 \\
\hline Pterostichus oblongopunctatus (F.) & 0.5 & $\mathrm{~F}$ & 27 & 4 & 15 & 276 & 138 \\
\hline Carabus glabratus Payk. & 0.5 & $\mathrm{~F}$ & 25 & 14 & 21 & 13 & 37 \\
\hline Pterostichus niger (Schall.) & 0 & $\mathrm{G}$ & 16 & 78 & 83 & 23 & 12 \\
\hline Carabus coriaceus $\mathrm{L}$. & 0.5 & $\mathrm{~F}$ & 13 & 19 & 8 & 2 & 2 \\
\hline Pseudoophonus rufipes (De Geer) & -0.5 & $\mathrm{O}$ & 4 & 24 & 2 & 0 & 7 \\
\hline Harpalus latus (L.) & 0 & $\mathrm{G}$ & 1 & 19 & 0 & 0 & 7 \\
\hline Platyderus rufus (Dft.) & 0 & G & 0 & 6 & 0 & 0 & 11 \\
\hline Notiophilus biguttatus (F.) & 0.5 & $\mathrm{~F}$ & 0 & 2 & 0 & 1 & 10 \\
\hline Amara communis (Panz.) & -0.5 & $\mathrm{O}$ & 0 & 11 & 0 & 0 & 1 \\
\hline Total number of individuals & & & 1441 & 454 & 998 & 1114 & 615 \\
\hline Total number of species & & & 23 & 33 & 18 & 19 & 21 \\
\hline
\end{tabular}

Abax carinatus (Dft.) 0.5 F, Amara aenea (De Geer) -1 O, Amara curta Dej. -1 O, Amara littorea C. G. Thom. -1 O, Amara similata (Gyll.) -1 O, Carabus cancellatus Ill. 0 G, Carabus intricatus L. +1 F, Cychrus attenuatus (F.) 1 F, Harpalus marginellus Dej. 0 G, Harpalus quadripunctatus Dej. 0.5 F, Harpalus signaticornis (Dft.) -1 O, Harpalus smaragdinus (Dft.) -1 O, Notiophilus rufipes Curt. 0.5 F, Ophonus nitidulus Steph. 0 G, Platynus assimilis (Payk.) 0.5 F, Pterostichus ovoideus (Sturm) 0 G, Synuchus vivalis Ill. -1 O, Panagaeus bipustulatus (F.) -0.5 O, Stomis pumicatus (Panz.) $0 \mathrm{G}$, Zabrus tenebrionides (Goeze) -1 O 
Table 2: Results of the repeated measures ANOVA for the total number of species, and for the species richness of the forest species, the open-habitat species and the generalist species. Stages (Beech forest, 5-, 15-, 30- and 50-y-old Norway spruce plantation) comprised the factor and the years (1998 and 1999) were used as repeated measures. Results of the Tukey's test indicate which stage $(\mathrm{s})$ differ(s) significantly $(\mathrm{P}<0.05)$ from the others; for example 'Beech $>15=30=$ $50>5$ ' indicates that the number of species was significantly higher in the beech forest than in the 15-, 30- and 50-y-old stages, moreover the catches of these latter three stages were significantly higher than in the 5-y-old stage.

\begin{tabular}{lccccccc}
\hline \multicolumn{1}{c}{ Variable } & Source & SS & df & MS & F & P & Tukey test \\
\hline Total species & Stage & 334.9 & 4 & 83.73 & 20.98 & $<0.001 \quad$ Beech $>5=15=30=50$ \\
& Error & 299.3 & 75 & 3.991 & & & \\
Forest species & Stage & 302.3 & 4 & 75.57 & 26.14 & $<0.001 \quad$ Beech $>15=30=50>5$ \\
& Error & 216.8 & 75 & 2.891 & & & \\
& Stage & 23.9 & 4 & 5.975 & 16.85 & $<0.001 \quad 5>$ Beech $=15=30=50$ \\
Open-habitat species & Error & 26.6 & 75 & 0.355 & & & \\
& Stage & 40.4 & 4 & 10.09 & 18.46 & $<0.001 \quad$ Beech $=5>15=30=50$ \\
Generalist species & Error & 41.0 & 75 & 0.547 & & & \\
\hline \hline
\end{tabular}


Table 3: Results of the repeated measures ANOVA for the forest affinity indices based on the frequency, specificity, fidelity and on a combination of specificity and fidelity. See Table 2 , for explanation of test procedures.

\begin{tabular}{|c|c|c|c|c|c|c|c|}
\hline Forest affinity index based on & Source & SS & df & MS & $\mathrm{F}$ & $\mathrm{P}$ & Tukey test \\
\hline \multirow[t]{2}{*}{ frequency $(F A I)$} & Stage & 0.895 & 4 & 0.224 & 20.93 & $<0.001$ & Beech $=30=50>15>5$ \\
\hline & Error & 0.802 & 75 & 0.011 & & & \\
\hline \multirow[t]{2}{*}{ specificity $(F S I)$} & Stage & 82.64 & 4 & 20.66 & 66.22 & $<0.001$ & Beech $>15=30=50>5$ \\
\hline & Error & 23.40 & 75 & 0.312 & & & \\
\hline \multirow[t]{2}{*}{ fidelity $(F F I)$} & Stage & 98.69 & 4 & 24.67 & 113.1 & $<0.001$ & Beech $>15=30=50>5$ \\
\hline & Error & 16.36 & 75 & 0.218 & & & \\
\hline \multirow[t]{2}{*}{ both specificity and fidelity ( $F S F I)$} & Stage & 35.14 & 4 & 8.79 & 204.3 & $<0.001$ & Beech $>30>15=50>5$ \\
\hline & Error & 3.225 & 75 & 0.043 & & & \\
\hline
\end{tabular}


Table 4: Results of the repeated measures ANOVA for the number of partial and obligate forest species, and for the ratio of the individuals of partial and obligate forest species to the total number of carabid individuals. See Table 2, for explanation of test procedures.

\begin{tabular}{|c|c|c|c|c|c|c|c|}
\hline Variable & Source & SS & $\mathrm{df}$ & MS & $\mathrm{F}$ & $\mathrm{P}$ & Tukey test \\
\hline \multirow[t]{2}{*}{ Number of partial forest species } & Stage & 173.0 & 4 & 43.25 & 21.05 & $<0.001$ & Beech $>15=30=50>5$ \\
\hline & Error & 154.1 & 75 & 2.055 & & & \\
\hline \multirow[t]{2}{*}{ Number of obligate forest species } & Stage & 23.41 & 4 & 5.853 & 19.06 & $<0.001$ & Beech $>5=15=30=50$ \\
\hline & Error & 23.03 & 75 & 0.307 & & & \\
\hline \multirow[t]{2}{*}{$\begin{array}{l}\text { Ratio of the individuals of partial forest } \\
\text { species to the total individuals }\end{array}$} & Stage & 2.48 & 4 & 0.620 & 30.33 & $<0.001$ & $30=50>$ Beech $=5=15$ \\
\hline & Error & 1.53 & 75 & 0.020 & & & \\
\hline \multirow{2}{*}{$\begin{array}{l}\text { Ratio of the individuals of obligate forest } \\
\text { species to the total individuals }\end{array}$} & Stage & 0.106 & 4 & 0.026 & 11.87 & $<0.001$ & Beech $>5=15=30=50$ \\
\hline & Error & 0.167 & 75 & 0.022 & & & \\
\hline
\end{tabular}


Table 5: Relationship between the number of carabid species (total, forest species, open-habitat species, generalist species, partial and obligate forest species) per trap and the age of the non-native Norway spruce plantation by linear regression analysis.

\begin{tabular}{|c|c|c|c|c|c|c|}
\hline & $\begin{array}{c}\text { Total number of } \\
\text { species }\end{array}$ & $\begin{array}{c}\text { Number of forest } \\
\text { species }\end{array}$ & $\begin{array}{c}\text { Number of } \\
\text { open-habitat } \\
\text { species }\end{array}$ & $\begin{array}{c}\text { Number of } \\
\text { generalist species }\end{array}$ & $\begin{array}{c}\text { Number of partial } \\
\text { forest species }\end{array}$ & $\begin{array}{c}\text { Number of obligate } \\
\text { forest species }\end{array}$ \\
\hline & $\mathrm{F}=4.37$ & $\mathrm{~F}=4.38$ & $\mathrm{~F}=12.73$ & $F=28.55$ & $\mathrm{~F}=7.64$ & $\mathrm{~F}=0.53$ \\
\hline & $\mathrm{df}=1,62$ & $\mathrm{df}=1,62$ & $\mathrm{df}=1,62$ & $\mathrm{df}=1,62$ & $\mathrm{df}=1,62$ & $\mathrm{df}=1,62$ \\
\hline & $\mathrm{P}=0.0408$ & $\mathrm{P}=0.0405$ & $\mathrm{P}=0.0007$ & $\mathrm{P}<0.0001$ & $\mathrm{P}=0.0076$ & $\mathrm{P}=0.4705$ \\
\hline & $\mathrm{r}=0.2565$ & $\mathrm{r}=0.2569$ & $\mathrm{r}=0.4128$ & $\mathrm{r}=0.5615$ & $\mathrm{r}=0.3312$ & $\mathrm{r}=0.0918$ \\
\hline Age of the plantation & Negative & Positive & Negative & Negative & Positive & Not significant \\
\hline
\end{tabular}


Table 6: Environmental variables contributing significantly (negatively or positively) as predictors of the species richness of the carabids by forward stepwise multiple linear regression analysis based on the data from the two study years. Variables not entered into the regression model are not listed. Notations: $\mathrm{ns}-$ not significant, $*-\mathrm{P}<0.05, * *-\mathrm{P}<0.01, * * *-P<0.001$

\begin{tabular}{|c|c|c|c|c|c|c|}
\hline & $\begin{array}{c}\text { Total number of } \\
\text { species }\end{array}$ & $\begin{array}{c}\text { Number of forest } \\
\text { species }\end{array}$ & $\begin{array}{c}\text { Number of } \\
\text { open-habitat } \\
\text { species }\end{array}$ & $\begin{array}{c}\text { Number of } \\
\text { generalist species }\end{array}$ & $\begin{array}{c}\text { Number of partial } \\
\text { forest species }\end{array}$ & $\begin{array}{c}\text { Number of } \\
\text { obligate forest } \\
\text { species }\end{array}$ \\
\hline & $\mathrm{F}=18.20$ & $F=20.66$ & $\mathrm{~F}=21.12$ & $\mathrm{~F}=28.34$ & $\mathrm{~F}=20.99$ & $\mathrm{~F}=20.35$ \\
\hline & $\mathrm{df}=4,75$ & $\mathrm{df}=4,75$ & $\mathrm{df}=5,74$ & $\mathrm{df}=4,75$ & $\mathrm{df}=3,76$ & $\mathrm{df}=3,76$ \\
\hline & $\mathrm{P}<0.0001$ & $\mathrm{P}<0.0001$ & $\mathrm{P}<0.0001$ & $\mathrm{P}<0.0001$ & $\mathrm{P}<0.0001$ & $\mathrm{P}<0.0001$ \\
\hline & $\mathrm{r}=0.7018$ & $\mathrm{r}=0.7241$ & $\mathrm{r}=0.7668$ & $\mathrm{r}=0.7758$ & $\mathrm{r}=0.6731$ & $\mathrm{r}=0.6674$ \\
\hline Cover of leaf litter & ns & $+^{*}$ & $-*$ & $+* *$ & ns & $+* * *$ \\
\hline Cover of herbs & ns & not entered & $+* *$ & not entered & not entered & not entered \\
\hline Cover of shrubs & not entered & not entered & $+* *$ & not entered & not entered & $\mathrm{ns}$ \\
\hline Canopy cover & $\mathrm{ns}$ & ns & $-* *$ & - ** & $+* * *$ & not entered \\
\hline Number of prey items & $+* *$ & ns & $+*$ & not entered & ns & not entered \\
\hline
\end{tabular}




\section{Figure Legends}

Figure 1. Mean number of species (a), forest species (b), open-habitat species (c), and generalist species (d) per trap (with S.E.).

Figure 2. Mean of the forest affinity index values (with S.E.) in the studied habitats based on (a) the frequency of species - FAI, (b) the specificity - FSI, (c) the fidelity - FFI and (d) a combination of specificity and fidelity - FSFI .

Figure 3. Nonmetric multidimensional scaling ordination (based on Helliger distance) of the pitfall-catches based on the two trapping years. 